\title{
GIS Application for Health Database System
}

\author{
Pranichayudha Rohsulina \\ Universitas Veteran Bangun Nusantara \\ Sukoharjo, Indonesia \\ rohsulinarohsulina@gmail.com
}

\author{
MS Khabibur Rahman \\ Universitas Veteran Bangun Nusantara \\ Sukoharjo, Indonesia \\ khabib_ynwa@yahoo.co.id
}

\author{
Eko Kuswanto \\ Universitas Veteran Bangun Nusantara \\ Sukoharjo, Indonesia \\ ekokuswanto026@gmail.com
}

\begin{abstract}
The aims of this study to make the health database system use the GIS application by combining spatial data with object attributes related to the distribution of health facilities supporting BPJS Health services in Sukoharjo District. This study uses qualitative descriptive, which explains or describes and knows the points of distribution location, as well as information other BPJS Health service support facilities on a map as a database are spatially illustrated using the GIS Application. The techniques for collecting data used are through field observations, and documentations. The results of this study are a database of health information contained in spatial data that can be shown on a map. The information contained therein is the location point and the name of the health facility supporting BPJS Health services, number of patient visits, facilities and infrastructure owned, and other attribute information related to a health facility at that location. Moreover, by using the GIS Application as a health database, it can be known that the health facilities supporting BPJS Health services in Sukoharjo District are included in the coordinates and regional information so that it is easier to understand.
\end{abstract}

Keywords-GIS application, health database, health facilities

\section{INTRODUCTION}

The GIS application is an application that contains spatial data and attribute data that can be added, stored, manipulated and recalled according to the user's wishes. The use of GIS applications has been widely used to create simple databases whose information will be displayed in spatial view. [2] said that "On the other hand, the development of spatial data utilization is progressing very rapidly. The development of technology combined with spatial data is able to answer the problem of the direction of development of the tourism object that has been constrained, one of them is the use of Geographic Information System (GIS). "

In the world of health, GIS has also begun to be used as a database in which there is spatial information on the location of health facilities, coordinates of health locations, attribute data on the number of visits, number of doctors, and other attribute data that can be added to the database system. GIS) is an ideal solution in mapping the existence of health facilities, both first and secondary levels. If BPJS Health clearly knows the existence and distribution patterns and knows the contents of attribute data from health facilities that collaborate with them, the BPJS will be able to direct the distribution of health facilities and increase or equipping health facilities based on data already owned. This cannot be done by only knowing the address of the health facility in a table, it requires a map that can provide information in a regional manner so that it can provide more easily understood information.

\section{A. Map and Geographic Information Systems (GIS)}

According to the guide book reading the Indonesian earth map, published by the National Coordinating Board and Survey (Bakosurtanal), describing the map is an illustration of natural and/or man-made elements, which are above and below the surface of the earth depicted on a flat plane. certain scale [5]. The map is the final product of a GIS application that can be made in hard file. The map in this case is a special map whose theme is based on the desire of the map maker based on attributes data that has been prepared in the database.

In the process of compiling the map there are several steps that must be taken, including data collection, data processing and reading or interpretation of maps [6]. For more details, the cartographic process can be seen in the following figure:

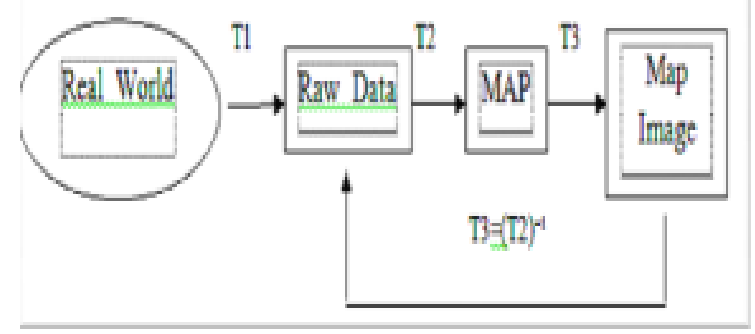

Figure 1. Cartographic process

Description:

Real World

T1

Raw data

: field data

T2 : Data processing process which includes analysis, classification and symbolization on maps (transforms).

Map

T3

: map generated

: reader and map interpretation

Map image : understanding / impression of a map reader

Geographic Information Systems is an information system that can combine spatial data with object, attribute data that is geographically connected on earth (georeference). In addition, this Geographic Information System can also combine data, organize, perform data analysis and then produce output in the form of maps. Data used in Geographic Information System (GIS) can generally be divided into 3 major parts: 
a. Graphical data

Graphical data are divided into raster data and digital data from these kinds of data will be explained as follows:

\section{1) Raster data}

Raster data are all digital data that is obtained from scanning results and other data that are not yet in vector format.

\section{2) Digital data}

Digital data are digital data obtained from digitization results that have been completed with text data and other attribute data. For example, the road network with its name, Watershed (DAS) with its tributaries.

b. Tabular data

Tabular data are data other than graphical data in the form of supporting data, in the form of text, numbers and other supporting data or table data that serves to explain the existence of various objects as spatial data. Data can be in the form of population censuses, survey records, other statistical and tabular data. Tabular data in GIS are also called attribute data. This tabular data will later be used as a database, which can be managed according to the user's wishes.

c. Vector data

Vector data is digital data or data that has been converted into digital form and has been equipped with object data or object information can be used as a reference in making decisions on geography problems. Geographic Information System software is now widely found in the market. Each software has developed with various facilities and applications. Such as AutoCAD MAP, LLWIS, Erdas, Ermapper, ArcView and so on [1].

\section{B. Health}

Health is a healthy condition, both physically, mentally, spiritually and socially, which allows everyone to live productively socially and economically. The government programmed the Social Security Organizing Agency abbreviated as BPJS is a legal entity established to organize social security programs (Law No. 24 of 2011). The BPJS consists of BPJS Health and Employment BPJS. BPJS Health is a legal entity established to organize a health insurance program. Health insurance is a guarantee in the form of health protection so that participants benefit from health care and protection to meet the basic health needs provided to everyone who has paid contributions or paid by the government.

Resources in the health sector are all forms of funds, personnel, medical supplies, pharmaceutical preparations and medical devices as well as health service facilities and technologies that are used to carry out health efforts carried out by the Government, local government, and / or the community. According to the Government Regulation of the Republic of Indonesia Number 47 of 2016 concerning Health Service Facilities. Health Facilities or Health Service Facilities are a tool or place that is used to organize health service efforts, both promotive, preventive, curative and rehabilitative carried out by the central government, regional government, and / or community. Health Service Facilities are established to provide good promoting health services, preventive, curative and rehabilitative. Health Care Facilities provide health services in the form of individual health services and public health services.

Types of Health Service Facilities consist of:

a) Independent practice place for health workers.

b) Community health centers.

c) Clinic.

d) Hospitals.

e) Pharmacy.

f) Blood transfusion unit

g) Health laboratory.

h) Optics.

i) Medical service facilities for legal and legal purposes

j) Traditional Health Care Facilities.

Health facilities contained in Sukoharjo District can be displayed in spatial form in the form of maps that are equipped with attribute data. GIS helps display the appearance of a map that can be adjusted based on the user's desires based on what attributes will be selected. The attribute information will adjust to its spatial appearance, but remains at the absolute location of each health facility.

\section{METHODS}

This study uses qualitative descriptive, which describes / describes and knows the locations of health service facilities supporting BPJS Health in Sukoharjo District, Sukoharjo District in various forms based on the attribute data in the database. Data in the form of the number of BPJS health service supporting health facilities can be obtained later by using absolute points in the field with GPS, then the data obtained is entered into the GIS application and added attribute data such as visitor level, number of doctors, and others.

\section{RESULT AND DISCUSSION}

Research has been done to find out the location point of BPJS health service supporting health facilities in Sukoharjo Subdistrict with absolute point taking in the field with GPS (Plotting area) so that the coordinates of each health facility are obtained, with the results in the following table. 
Table 1. Distribution of Health Facilities Supporting BPJS Health Services Sukoharjo District

\begin{tabular}{|c|c|c|c|c|c|}
\hline No & Heal th Name & Owner & Address & Latitude & $\begin{array}{c}\text { Line } \\
\text { Address }\end{array}$ \\
\hline 1 & $\begin{array}{l}\text { Sukoharjo } \\
\text { Health Center }\end{array}$ & Sukoharjo Regency & Sukoharjo & $\begin{array}{l}110^{\circ} 50^{\prime} 1 \\
0.19^{\prime}\end{array}$ & $\begin{array}{l}7^{\circ} 40^{\prime} 32 . \\
74^{r}\end{array}$ \\
\hline 2 & $\begin{array}{l}\text { Nirmala Suri } \\
\text { Hospital }\end{array}$ & $\begin{array}{l}\text { Dr. Harun Roscid } \\
\text { Sp.b.Mars }\end{array}$ & Bulakrejo & $\begin{array}{l}110^{\circ} 50^{\prime} 3 \\
0.44^{\circ}\end{array}$ & $\begin{array}{l}7^{\circ} 40^{\prime} 50 \\
01^{-}\end{array}$ \\
\hline 3 & $\begin{array}{l}\text { PKU } \\
\text { Muhammadiy } \\
\text { ah Hospital }\end{array}$ & $\begin{array}{l}\text { Muhammadiyah } \\
\text { Regional Leadership } \\
\text { of Sukoharjo } \\
\text { Regency }\end{array}$ & Sukoharjo & $\begin{array}{l}110^{\circ} 50^{\prime} 2 \\
3.01^{-}\end{array}$ & $\begin{array}{l}7^{\circ} 40^{\prime} 39 . \\
40^{\circ}\end{array}$ \\
\hline 4 & $\begin{array}{l}\text { Clinic of } \\
\text { Pratama PPK } \\
\text { I }\end{array}$ & $\begin{array}{l}\text { Police Officer of } \\
\text { Sukoharjo }\end{array}$ & Sukoharjo & $\begin{array}{l}110^{\circ} 50^{\prime} 1 \\
1.04^{\tau}\end{array}$ & $\begin{array}{l}7^{\circ} 40^{\prime} 29 . \\
81^{-}\end{array}$ \\
\hline 5 & $\begin{array}{l}\text { Clinic of } \\
\text { Pratama Mitra } \\
\text { Sehat }\end{array}$ & dr. Aulia & Jetis & $\begin{array}{l}110^{\circ} 49^{\prime} 5 \\
8.63^{-}\end{array}$ & $\begin{array}{l}7^{\circ} 40^{\prime} 53 . \\
17^{\circ}\end{array}$ \\
\hline 6 & $\begin{array}{l}\text { Clinic } \\
\text { Pratama The } \\
\text { Clinic }\end{array}$ & dr. Aurea Ekanti & Jetis & $\begin{array}{l}110^{\circ} 50^{\prime} 1 \\
9.47^{\circ}\end{array}$ & $\begin{array}{l}7^{\circ} 40^{\prime} 47 . \\
69^{\circ}\end{array}$ \\
\hline 7 & $\begin{array}{l}\text { Clinic } \\
\text { Pratama } \\
\text { Latifa Husada }\end{array}$ & Dr. Ary Pardiyanto & Banmati & $\begin{array}{l}110^{\circ} 49^{\prime} 1 \\
1.16^{\circ}\end{array}$ & $\begin{array}{l}7^{\circ} 42^{\prime} 26 . \\
92^{-}\end{array}$ \\
\hline 8 & $\begin{array}{l}\text { Praktek dr. } \\
\text { Arsita Rasmi }\end{array}$ & dr. Arsita Rasmi & Joho & $\begin{array}{l}110^{\circ} 50^{\prime} 3 \\
1.33^{-}\end{array}$ & $\begin{array}{l}7^{\circ} 42^{\prime} 23 . \\
85^{\circ}\end{array}$ \\
\hline 9 & $\begin{array}{l}\text { Praktek drg. } \\
\text { Henny } \\
\text { Susanti }\end{array}$ & drg. Henny Susanti & Joho & $\begin{array}{l}110^{\circ} 50^{\prime} 1 \\
7.84^{*}\end{array}$ & $\begin{array}{l}7^{\circ} 41^{\prime} 31 . \\
44^{\tau}\end{array}$ \\
\hline 10 & $\begin{array}{l}\text { Praktek Dr. } \\
\text { Indarto }\end{array}$ & Dr. Indarto & Bulakan & $\begin{array}{l}110^{\circ} 47^{\prime} 3 \\
4.62^{-}\end{array}$ & $\begin{array}{l}7^{\circ} 40^{\prime} 32 . \\
74^{\circ}\end{array}$ \\
\hline 11 & $\begin{array}{l}\text { Kimia Farma } \\
\text { Drugstore }\end{array}$ & Indonesia & Jetis & $\begin{array}{l}110^{\circ} 50^{\prime} 2 \\
3.98^{\circ}\end{array}$ & $\begin{array}{l}7^{\circ} 40^{\prime} 55 \\
62^{*}\end{array}$ \\
\hline 12 & $\begin{array}{l}\text { Gendon } \\
\text { Optics }\end{array}$ & Fathur & Gayam & $\begin{array}{l}110^{\circ} 50^{\prime} 4 \\
2.58^{\circ}\end{array}$ & $\begin{array}{l}7^{\circ} 40^{\prime} 59 . \\
53^{-}\end{array}$ \\
\hline 13 & $\begin{array}{l}\text { Sari Asih } \\
\text { Optics }\end{array}$ & Heman Giyono & Gayam & $\begin{array}{l}110^{\circ} 50^{\prime} 3 \\
0.44^{\tau}\end{array}$ & $\begin{array}{l}7^{\circ} 40^{\prime} 50 . \\
01^{-}\end{array}$ \\
\hline
\end{tabular}

The data obtained is then processed in the GIS Application by entering the name of the health facility and the coordinates of latitude and longitude have changed in decimal form, can be seen in the following figure:

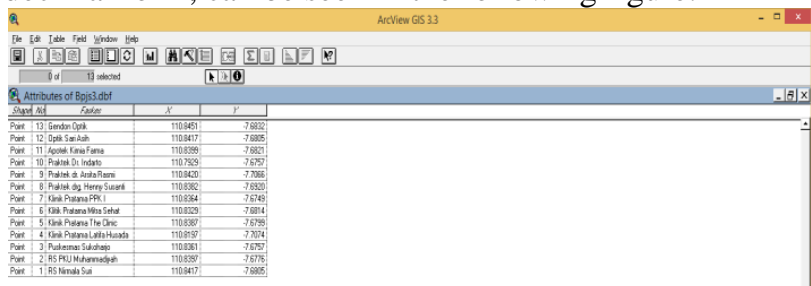

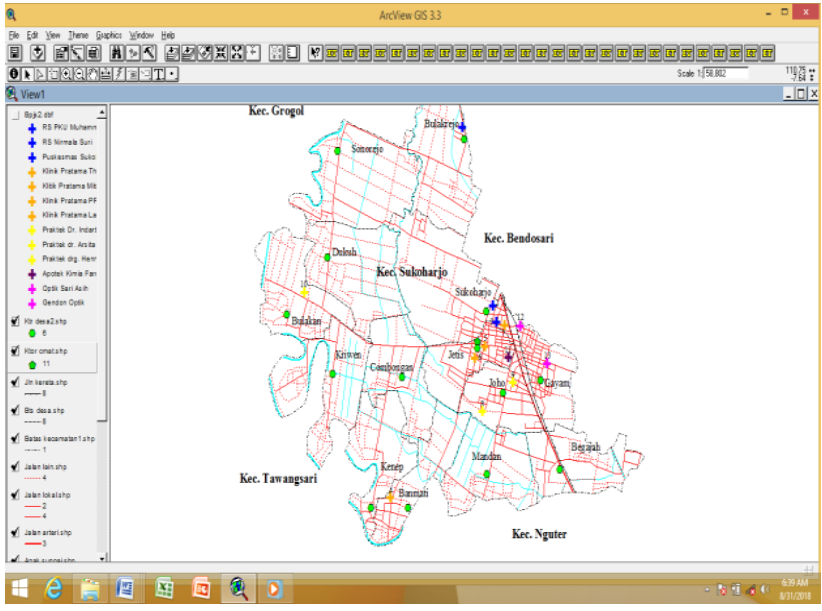

Figure 3. Processing of attribute data in GIS

Health The data entered is processed by providing the appropriate symbol along with information to distinguish one facility from another to make it easier to read a map and add map attributes as additional information on maps such as roads, government offices, administrative boundaries, rivers and so on. In the picture above, we can see the location of health facilities plus regional information so that it is easier to understand, which can later be used as a health database.

The next process is to complete the map component in accordance with the Cartographic rules. The processing is done on the Layout contained in the GIS Application. In the data processing in Layout the addition of map components is done to add the information needed to read a map so that it is easier for the reader to quickly understand what is meant in the map. The results of the distribution of health facilities supporting BPJS health services can be seen in the following figure:

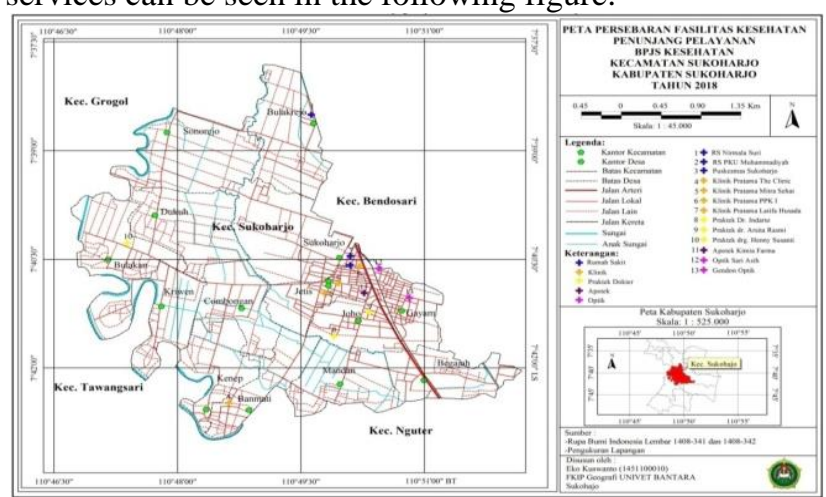

Figure 4. Map of distribution of health facilities resulting from processing attributes data on GIS

Adding attribute data to the GIS system that is used as a database is carried out in accordance with the wishes of the map maker. In this study attribute data added is the number of visits before the BPJS service and after the BPJS service. The database, display on GIS after adding visit information on each health facility can be seen in the following figure: 


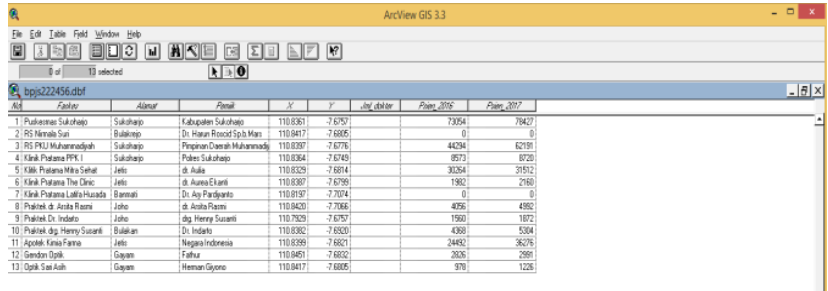

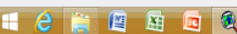

Figure 5. Display GIS database that already has an additional attribute data

Patient visit data before the BPJS service and after the BPJS service can show a change in the number of visitors, there are health facilities that have increased and there are health facilities that have decreased the number of visits. Changes in the number of visitors at each health facility can be seen in one map to facilitate reading like the picture below:

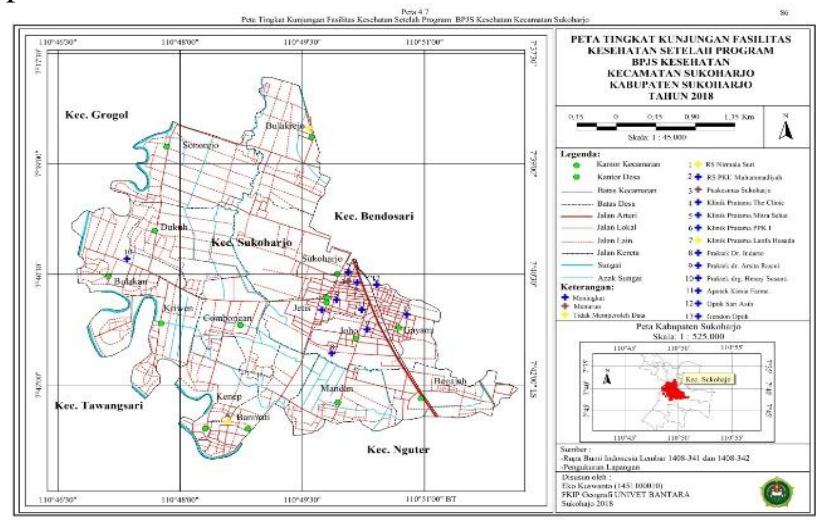

Figure 6. Map of changes in the number of health facility visits processed from attribute data based on database entries

The description of the map above shows that there are 13 health facilities supporting BPJS health services in Sukoharjo District. Health facilities that experienced an increase in the number of visitors were 10 health facilities. Unlike the previous map, this map illustrates changes in the number of visitors at each health facility.

The utilization of GIS applications in the world of health is very important where one of its functions can be used as a database in the health field whose function is to store health information about the absolute location spatially, location and other information such as number of visits, number of doctors, and other attribute information so that readers have more understanding that is broad and easier than just reading tables. In this study, the GIS application was used as a health database regarding the distribution of BPJS health services supporting health facilities in Sukoharjo Subdistrict, from the results of the study there were 13 health services supporting BPJS Health services which were government programs provided to BPJS Health participants including health facilities in Sukoharjo Health Center, Nirmala Suri Hospital, PKU Muhammadiyah Hospital, Clinic of Pratama PPK I , Clinic of Pratama Mitra Sehat, Clinic Pratama The Clinic, Clinic Pratama Latifa Husada, Praktek dr. Arsita Rasmi, Praktek drg. Henny Susanti, Praktek Dr. Indarto, Kimia Farma Drugstore, Gendon Optics, Sari Asih Optics, there are 7 sub-distric, namely Sukoharjo, Bulakrejo, Jetis, Banmati, Joho, Bulakan and Gayam, while 7 other sub-distric do not have health facilities that support the BPJS Health.

Health services while 7 other villages do not yet exist, this needs to be considered for the government as a reference to improve health services for public health. By looking at the database spatially about the distribution of health facilities, it can be used as a reference for even distribution of additional health support facilities for BPJS Health services Sukoharjo sub-district has 14 subdistricts, but only 7 sub-districts have health facilities that support BPJS in areas far from health facilities, so as to make it easier for the community to seek treatment as needed.

The advantage of using a database in a GIS application is that users are facilitated to process and display data in accordance with the user's wishes. The data displayed will be directly linked to the location of the object in question, in this case health facility.

\section{RESULT AND DiSCUSSION}

The results showed that the GIS application could be used as a health database which included information on the distribution of health services supporting BPJS Health in Sukoharjo District, regarding the absolute location, number of visits, number of doctors, and the presence in each village in Sukoharjo Subdistrict. This research provides an overview of spatial information and information so that it can provide a broad view of the reader, all on the map as a result of the GIS application that functions as a database. Utilization of the GIS Application as a database should be further optimized to be used in the health and other fields so as to provide optimal information and ease of presenting data.

\section{REFERENCES}

[1] Andi. Sistem Informasi Geografi dengan AutoCAD MAP. Yogyakarta: Wahana Komputer Semarang, 2005.

[2] Partono, Bambang, and MS Khabibur Rahman. "Development of Tourism Site on the Narrow Land (Case Study Dam Colo, Nguter District of Sukoharjo)." International Journal of Research in Tourism and Hospitality (IJRTH), vol 3, no. 4, 2017, pp. 25$29,2017$.

[3] Mulyawan, Ketut Hari. "Analisis Spasial Keberadaan Fasilitas Health Tingkat Pertama (FKTP) Di Denpasar, Badung Dan Tabanan", 2015.

[4] Peraturan Pemerintah Republik Indonesia Nomor 47 Tahun 2016 Tentang Fasilitas PelayananHealth (Salinan). 2016.

[5] Rahman,MS Khabibur \& Rohsulina, Pranichayudha. Pemetaan Sarana Prasarana SD Negri di Kecamatan Sukoharjo Berdasarkan permendiknas Nomor 24 Tahun 2007. Jurnal GEOEDUKASI, 4 (1), 49-54, 2015.

[6] Rohsulina, Pranichayudha.dkk. (2015). Analisis Persebaran Daerah Asal Mahasiswa Universitas Veteran Bangun Nusantara dengan Menggunakan Sistem Informasi Geografis (SIG). Jurnal GEOEDUKASI, 2015. 